\title{
Sanding of drained peatlands
}

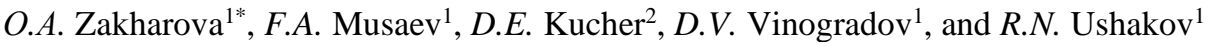 \\ ${ }^{1}$ Ryazan State Agrotechnological University named after P.A. Kostychev, 390044 Ryazan, Russia \\ ${ }^{2}$ Institute of the Peoples' Friendship University of Russia (RUDN), Research and Design Institute, 117198 Moscow, Russia
}

\begin{abstract}
The results of many years of original research based on soil-ecological monitoring showed the development of degradation processes of previously drained peat soils of the Ryazan Meshchera. Structural amelioration (sanding) of peat soils had some positive effect. The aim of the research was to study the properties of the dried peat soil at reclamation site Tinki-II in the settlement of Polkovo, Ryazan District of Ryazan Region, as a result of sanding. The most common type of German mixed-layer sanding was used in investigations. The methodology was based on the principle of comparing the state of dried peat soil before and after sanding. The content of the less than $0.01 \mathrm{~mm}$ fractions was $4.3 \%$, the rest consisted of particles from 0.25 to $0.05 \mathrm{~mm}$; the $\mathrm{pH}$ of the salt extract was 5.7. Mineral fertilizers were applied in the experiment in small quantities: ammonium nitrate $-180 \mathrm{~g}$, superphosphate $-185 \mathrm{~g}$ and potassium sulfate $-260 \mathrm{~g}$. The water supply was atmospheric-ground. Variant 2 was more effective - sanding with a dose of $1200 \mathrm{t} / \mathrm{ha}$ for sluicing and maintaining GWL $=90 \mathrm{~cm}$, as evidenced by improved water-physical properties of the soil: the total porosity increased by $5 \%$; the total water capacity decreased from 270 to $70 \%$, that was almost 4 times. Keywords: peat soil, degradation, sluicing, sanding, yield, potato.
\end{abstract}

\section{Introduction}

Peatlands are categorized as exhaustible and nonrenewable soil-geological formations. Land reclamation measures projected on them should be coordinated with the main tasks of agriculture, built in full relation with the nature of their organogenic origin and the specification of irreversible processes occurring in peat as a result of drainage [1].

Member of the Russian Academy of Agricultural Science B.S. Maslov stated: "The urgent task of science and production workers in modern conditions is the inspection and inventory of previously built irrigation and drainage systems" [2].

The results of many years of original research based on soil-ecological monitoring showed the development of degradation processes of previously drained peat soils of Ryazan Meschera. Degradation was the result of irrational use of soil, violation of drainage norms and indifference to drainage systems in general after the collapse of the USSR.

In previously published authors' works [3-5], we noted a peat drawdown of $54 \ldots 67 \mathrm{~cm}$, the appearance of wet spots indicating secondary waterlogging, deterioration of water-physical properties, an increase in ash content and the surface sand deposits. All this led to the development of the motley topsoil, reduction of peat layer thickness to $116 \mathrm{~cm}$, loss of organic matter by 120 $\mathrm{t} /$ ha and other negative changes.

Structural reclamation (sanding) of peat soils has obvious effect. There are three types of sanding: mixed (or northern, Swedish), blanket (bulk or Rimpau) and German mixed-layer. In addition, there is the black culture, under the conditions of which peat soils are used without making mineral additives. Mixed sanding is the introduction of sand in the plowed horizon and its mixing with peat when plowing [6].

Long-term studies of the mixed sanding method, carried out by the Swedish society for wetlands, showed some significant improvement in physical properties and thermal conditions, better processing conditions for such soils and faster ripening of cultivated crops [7].

In addition, scientific information contains information on the promotion of mixed sanding to accelerate the rate of biochemical depletion of peat from the arable horizon as a result of increased aeration and oxidation.

In Germany, where this technique is recognized as mandatory in the development of organogenic soils, it is called a mixed sand culture - Sandmischkultur. This method of land reclamation helps improve the physical and chemical properties of water, heat and nutrient regimes of peat soils.

In Russia, apparently, the first message on sanding of drained peat soils was published in 1899 in the Brockhaus and Efron encyclopedic dictionary (1899) in a special article "Rimpau". When blanket sanding, an arable sandy horizon with a capacity of $14-16 \mathrm{~cm}$ with a subsequent plowing of $2-3 \mathrm{~cm}$ peat for its organic matter enrichment is created on the surface of the peat soil. This technique is called the blanket (Sanddeckkultur) or Rimpau (by the name of the landowner Rimpau, who

\footnotetext{
* Corresponding author: ol-zahar.ru@ yandex.ru
} 
proposed this method of using drained peat soils for the first time in 1887). To lay the arable sandy layer on the surface of dried peat soils, it is necessary to place 1,800 $2,200 \mathrm{t} / \mathrm{ha}$ of sand. The process of forming a sandy horizon is expensive and time-consuming, but after 2-3 years it is paid back by some additional crop.

The advantage of this agromeliorative method is its long after-action. The advantages also include a sharp increase in the carrying capacity of the soil, improvement of the working conditions of agricultural machinery and vehicles, reduction or elimination of the threat of fires and reduction of the risk of erosion, removal of organic peat matter with the crop and full mechanization of work.

In Germany, an auger device mounted on a tractor is widely used. The peculiarity of such a device is that it takes out sand underlying peat on the surface. With the help of a screw device, sand is thrown onto the soil surface with a belt of 6-7 m wide in one pass of the machine. Then the deep furrow that appears after the auger work is filled with peat using a tiller.

Thus, there is ambiguous information in the literature about the possible improvement of drained peat soils by sanding, which requires clarification taking into account the soil-climatic and organizational-economic features [8-10].

The aim of the research was to study the properties of the dried peat soil at reclamation site Tinki-II in the settlement of Polkovo, Ryazan District of Ryazan Region, as a result of sanding.

The scientific novelty consisted in sanding degraded peat soils when regulating the level of groundwater by sluicing in Ryazan Meschera.

Characteristics of the land-reclamation facility and peat soil have been published previously. The filtration coefficient of peat was equal to $0.38 \mathrm{~m} /$ day and the density was $1.42 \mathrm{~g} / \mathrm{cm}^{3}$. We used the most common type of German mixed-layer sanding.

The object of study was peat soil with a long drainage period. Figure 1 presents illustrations of the retrospective and current state of the reclaimed territory of Ryazan Meschera.

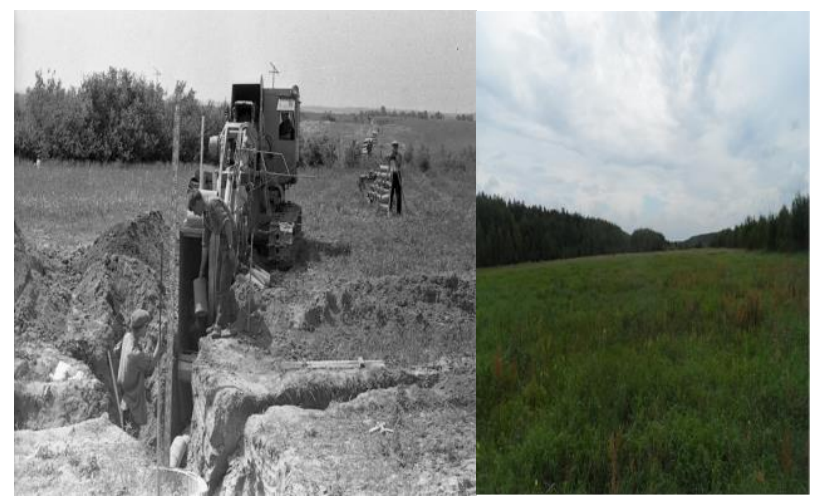

Fig. 1. General view of the site in 1956 and 2018

The methodology was based on the principle of comparing the state of dried peat soil before and after sanding.

The experiment included the following variants for a two-factor field micro-plot experiment when sluicing with a decrease in the GWL in the area up to 90 and $120 \mathrm{~cm}$ : control - without sanding; experimental variants: when reducing GWL to $90 \mathrm{~cm}$ : variant $1-$ sanding at the rate of $800 \mathrm{t} / \mathrm{ha}$; variant 2 - sanding at the rate of $1,200 \mathrm{t} / \mathrm{ha}$; variant 3 - sanding at the rate of 2,000 t/ha and when reducing the GWL to $120 \mathrm{~cm}$ : variant 4 - sanding at the rate of $800 \mathrm{t} / \mathrm{ha}$; variant 5 sanding at the rate of $1,200 \mathrm{t} / \mathrm{ha}$; variant 6 - sanding at the rate of 2,000 t/ha.

The size of each plot was 2.5 by $3.0 \mathrm{~m}$. The total area of the plot was $7.5 \mathrm{~m}^{2}$, and the registration area was $3 \mathrm{~m}^{2}$. The allocation of plots was systematic and the replication was six-fold.

By particle size, the sand was loose, fine-grained. The content of fractions less than $0.01 \mathrm{~mm}$ was $4.3 \%$, the remaining part included particles from 0.25 to $0.05 \mathrm{~mm}$ and the $\mathrm{pH}$ of the salt extract was 5.7. The sand filtration coefficient was $6.18 \mathrm{~m} /$ day and the density was $2.62 \mathrm{~g} / \mathrm{cm}^{3}$.

In the experiment, mineral fertilizers were applied in small quantities: $180 \mathrm{~g}$ of ammonium nitrate, $185 \mathrm{~g}$ of superphosphate and $260 \mathrm{~g}$ of potassium sulfate.

Water nutrition was atmospheric and soil. The TinkiII object was dried by closed drainage in combination with open main and upland-hunting channels. The method of observation of the groundwater level, its measurement by a check valve and sluicing were adopted in accordance with "Occasional methodological guidelines for water balance stations on reclaimed land for observations and processing of materials". At each site, observation wells were installed beyond the groundwater level (GWL).

It was problematic to perform sluicing on the entire main drainage channel of the Tinki-II ameliorative object because of the only control structure; others were disassembled and put into scrap. This explained the choice of the experimental site, which was located at a distance from the village.

The humidity and temperature of the soil was measured with a tensiometer with subsequent recalculation of readings according to the calibration curve. The bulk density, $\mathrm{g} / \mathrm{cm}^{3}$, was determined when drying by the calculation method. The total porosity was calculated by the following formula:

$$
\mathrm{P}_{\text {total }}=100\left(1-\frac{D}{d}\right)
$$

where $D$ is the bulk density, $d$ is the specific density of soil, $\%$.

Full moisture capacity was determined by calculation. Nitrate nitrogen content was analyzed according to GOST R 53219-2008 "Soil quality".

The cellulose-destructive activity of the soil was determined according to the Zvyagintsev method with an exposure period of three months. Glasses $10 \times 10 \mathrm{~cm}$ were sheathed by a pre-weighed linen cloth and placed in the soil to a depth of $20 \mathrm{~cm}$. They were removed from the soil alternately in 1,2 and 3 months. The replication was threefold.

Potato variety Almera was zoned in Ryazan region and introduced into the State Register in 2009. The originator was company AGRICO U.A. (Netherlands). 
This is a mid-early table variety with oval tubers. Vegetation duration is 65-80 days. The productivity is up to $400 \mathrm{~kg} / \mathrm{ha}$. Agrotechnology of potatoes in the experiment was generally accepted in the region, taking into account the specifics of field micro-plot experiment.

The reliability of the experimental results was determined using Statistica 10 software package. When working in the program, the Statistics and Graphs options were used.

The heat and moisture provision was monitored according to the data of the automatic meteorological station SEBA with the recording of meteorological factors by a microprocessor installed in Polkovo. 2016 had a hydrothermal coefficient (HTC) equal to $1.2-$ excessively wet, 2017 had HTC $=1.4$ - excessively wet, and 2018 had HTC $=1.0-$ consistent with the average multi-year parameters.

During the years of investigations, weather conditions differed in terms of heat and moisture, which made it possible to more fully identify the characteristics of changes in soil properties and the formation of potato yields.

\section{Results and discussion}

As a result of sanding, there was a change in the waterphysical properties of the peat soil (bulk density, pore volume, total moisture capacity (TMC)), that is shown in Table 1.

Table 1. The change in the bulk density of peat soil under the influence of sanding

\begin{tabular}{|c|c|c|c|}
\hline Variants & $\begin{array}{c}\text { Bulk } \\
\text { density, } \\
\text { g/cm }\end{array}$ & $\begin{array}{c}\text { Pore } \\
\text { volume, } \\
\%\end{array}$ & $\begin{array}{l}\mathrm{TM} \\
\mathrm{C}, \%\end{array}$ \\
\hline $\begin{array}{l}\text { Control - without } \\
\text { sanding }\end{array}$ & 0.23 & 76.3 & $\begin{array}{c}270 . \\
0\end{array}$ \\
\hline \multicolumn{4}{|c|}{ when reducing GWL to $90 \mathrm{~cm}$} \\
\hline $\begin{array}{c}\text { Variant } 1 \text { - sanding } \\
\text { at the rate of } 800 \\
\text { t/ha }\end{array}$ & 0.44 & 53.2 & $\begin{array}{c}135 . \\
8\end{array}$ \\
\hline $\begin{array}{c}\text { Variant } 2 \text { - sanding } \\
\text { at the rate of } 1,200 \\
\text { t/ha }\end{array}$ & 0.60 & 54.0 & 80.5 \\
\hline $\begin{array}{l}\text { Variant } 3 \text { - sanding } \\
\text { at the rate of } 2,000 \\
\text { t/ha }\end{array}$ & 0.82 & 55.0 & 69.5 \\
\hline \multicolumn{4}{|c|}{ when reducing the GWL to $120 \mathrm{~cm}$} \\
\hline $\begin{array}{c}\text { Variant } 4 \text { - sanding } \\
\text { at the rate of } 800 \\
\text { t/ha }\end{array}$ & 0.50 & 53.8 & 80.3 \\
\hline $\begin{array}{l}\text { Variant } 5 \text { - sanding } \\
\text { at the rate of } 1,200 \\
\text { t/ha }\end{array}$ & 0.62 & 55.8 & 74.2 \\
\hline $\begin{array}{c}\text { Variant } 6 \text { - sanding } \\
\text { at the rate of } 2,000 \\
\text { t/ha }\end{array}$ & 0.80 & 57.5 & 72.4 \\
\hline
\end{tabular}

According to the information in Table 1, the bulk density in the arable layer of the soil increased from 0.23 to $0.82 \mathrm{~g} / \mathrm{cm}^{3}$, that is, increased almost 4-fold. In terms of the mechanical composition of the soil, variants 4,5 and 6 with a decrease in GWL to $120 \mathrm{~cm}$ became more mineralized. The total moisture capacity has significantly decreased. If before sanding it was $270.0 \%$, then with a sand dose of $2.000 \mathrm{t} / \mathrm{ha}$ with $\mathrm{GWL}=90 \mathrm{~cm}$, it was $69.5 \%$, i.e. decreased by $25 \%$ and with the introduction of the same dose with GWL $=120 \mathrm{~cm}-$ by $72 \%$. The same parameters on variants 4 and 5 with a drop in the GWL to $120 \mathrm{~cm}$ were lower, except for the pore volume, which, in our opinion, is a direct consequence of a change in the water regime of the site.

The main factor in the loss of organic matter was its mineralization. The change in the organic matter reserves of drained peat soil in variant 2 is presented in dynamics over the years in Table 2 .

Table 2. Change in organic matter in drained peat soils

\begin{tabular}{|c|c|c|c|c|c|c|c|c|}
\hline \multirow{2}{*}{$\begin{array}{c}\text { Recla- } \\
\text { mation } \\
\text { object }\end{array}$} & \multicolumn{3}{|c|}{ Peat deposit, $\mathrm{cm}$} & \multicolumn{5}{|c|}{ Mass of organic matter, $\mathrm{t} / \mathrm{ha}$} \\
\hline & 1960 & $\begin{array}{r}\text { Befor } \\
\text { af } \\
\text { sand } \\
20\end{array}$ & $\begin{array}{l}\text { e and } \\
\text { er } \\
\text { ing, } \\
18\end{array}$ & 1960 & $\begin{array}{r}\mathrm{Be} \\
\text { and } \\
\text { san } \\
2\end{array}$ & $\begin{array}{l}\text { fore } \\
\text { after } \\
\text { ling, } \\
18\end{array}$ & $\begin{array}{r}\mathrm{Be} \\
\text { and } \\
\text { san } \\
2 \\
\text { ave } \\
\text { an } \\
\text { dec } \\
\mathrm{t}\end{array}$ & $\begin{array}{l}\text { ore } \\
\text { after } \\
\text { ling, } \\
18 \\
\text { age } \\
\text { ual } \\
\text { ease, } \\
\text { la }\end{array}$ \\
\hline $\begin{array}{l}\text { Tinki- } \\
\text { II }\end{array}$ & 151.6 & 119.3 & $\begin{array}{c}120 . \\
2\end{array}$ & 2.843 & 2.79 & 2.80 & 2.4 & 2.0 \\
\hline
\end{tabular}

From the data given in Table 2, a direct relationship between sanding and the growth of organic matter is clearly traced. So, for example, after a single application of sand mass after three years, the thickness of the peat deposit increased by almost $1 \mathrm{~cm}$, and the mass of organic matter as a whole increased by $5 \mathrm{t} / \mathrm{ha}$. Given the effect of sanding for at least 5 years, we can theoretically double the growth of organic matter.

The average annual loss of organic matter decreased by $17 \%$, that is, there is a positive trend in the change of agrochemical parameters.

The humus content in peat soil in variant 2 increased by $0.02 \%$, which is associated with the introduction of fertilizers, activation of the microbial population of the soil and insignificant plant litter. The content of humic substances $(\mathrm{C} * 2)$ increased from 49.5 to $50.3 \%$ of the organic mass, and $\mathrm{C}$ of humic substances - from 58.6 to $59.1 \%$ of the $S_{\text {gross }}$.

The maximum accumulation of humic substances was observed in the middle part of the soil profile (20$30 \mathrm{~cm}$ ), which is explained by their greater biological resistance to the destructive action of microorganisms in conditions of aerated soil, but, in the authors' opinion, it is largely explained by the migration of humic substances down the profile.

Humic acids, being a product of biochemical transformations of plant residues, take part in the regulation of the most important soil properties and 
stimulate plant growth. Humic acids predominate in humus, as shown in Table 3.

Table 3. The composition of humic substances in soils

\begin{tabular}{|c|c|c|c|c|}
\hline $\begin{array}{c}\text { Reclamation } \\
\text { object }\end{array}$ & $\begin{array}{c}\text { Layer } \\
\text { depth } \\
\text { cm }\end{array}$ & CHA & CFA & CHA/CFA \\
\hline Tinki-II & $0-10$ & 28.14 & 6.47 & 4.35 \\
& $10-20$ & 25.07 & 7.98 & 3.14 \\
& $20-30$ & 28.71 & 8.17 & 3.51 \\
\hline
\end{tabular}

According to Zvyagintsev, the cellulose-destructive activity of the soil is very high (Table 4).

Ultimately, the optimization of peat soil fertility by sanding affected its productivity: the potato crop in variant 2, while maintaining the GWT at $90 \mathrm{~cm}$, was quite high and amounted to $130 \mathrm{~kg} / \mathrm{ha}$, or $144 \%$ compared with the control. Maintaining a groundwater level of $120 \mathrm{~cm}$ increased the yield of potatoes by $136 \%$.

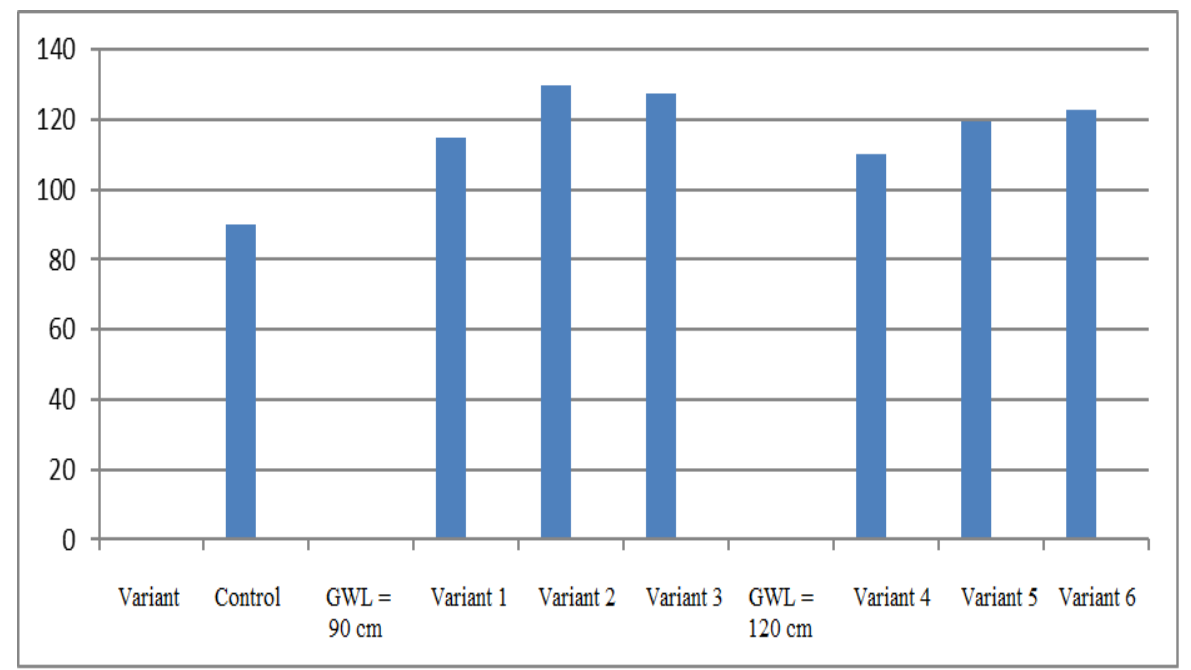

Fig. 2. Yield (dt/ha) of potatoes, depending on the dose of sanding and maintaining the set level of groundwater

Prior to the economic transformations in the country, dual regulation of the water regime was applied at reclamation object Tinki-II. Irrigation was carried out by sprinkling, which, in our opinion, would ensure the replenishment of moisture deficit in the soil and atmosphere, which was observed during the growing season of each study year up to $5 \ldots 8$ times. Unfortunately, the irrigation network was dismantled in the mid-1990s.

\section{Conclusion}

Sanding lowland peat soils is of significant agroeconomic interest as one of the methods for optimizing fertility. Variant 2 is more effective - sanding with a dose of 1,200 t/ha at sluicing and maintaining GWL $=90$ $\mathrm{cm}$, as evidenced by the improvement of water-physical properties of the soil. The pore volume increased by $5 \%$; the capacity of peat mass increased by almost $1 \mathrm{~cm}$, and the mass of organic matter as a whole increased by $5 \mathrm{t} / \mathrm{ha}$; the average annual loss of organic matter decreased by $17 \%$; the total moisture capacity decreased
Table 4. Cellulose-destructive activity of the soil (average data; the mass of linen before laying in the soil is $6.5 \mathrm{~g}$ )

\begin{tabular}{|c|c|c|c|c|}
\hline $\begin{array}{c}\text { Expositio } \\
\mathrm{n} \text { period, } \\
\text { months }\end{array}$ & $\begin{array}{c}\text { The mass of } \\
\text { the linen } \\
\text { after the } \\
\text { experiment, } \\
\mathrm{g}\end{array}$ & $\begin{array}{c}\text { The mass } \\
\text { of } \\
\text { decompo- } \\
\text { sition, } \\
\mathrm{g}\end{array}$ & $\begin{array}{c}\% \text { to } \\
\text { the } \\
\text { original } \\
\text { mass }\end{array}$ & $\begin{array}{c}\text { Degree of } \\
\text { decompo- } \\
\text { sition } \\
\text { according } \\
\text { to } \\
\text { Zvyagintse } \\
\mathrm{v}\end{array}$ \\
\hline \multicolumn{5}{|c|}{ Tinki-II } \\
\hline 1 & 3.86 & 2.64 & 40.61 & average \\
\hline 2 & 2.44 & 4.06 & 62.46 & high \\
\hline 3 & 1.65 & 4.85 & 74.62 & high \\
\hline \multicolumn{5}{|c|}{ Variant 2} \\
\hline 1 & 2.70 & 3.80 & 58.46 & average \\
\hline 2 & 1.96 & 4.54 & 69.85 & high \\
\hline 3 & 0.85 & 5.65 & 89.92 & very high \\
\hline
\end{tabular}

from 270 to $70 \%$, that is, almost 4 times and potato yield increased by $44 \%$.

\section{References}

1. M.G. Mustafayev, Yu.A. Mazhayskiy, Diagnostic Parameters of Irrigated Meadow-Serozemic and Alluvial-Meadow Soils of the Mugan-Sal'yany Massif of Azerbaijan Rus. Agric. Sci. 44(6), 551-558 (2018)

2. O.A. Zakharova, D.V. Vinogradov, N.V. Byshov, F.A. Musaev, Results of Monitoring Studies of Dried Peat Soils Int. J. of Advanced Biotechn. and Res. (IJABR) 10(2), 474-489 (2019)

3. A. Ilieva, V. Vasileva, Effect of liquid organic humate fertilizer Humustim on chemical composition of spring forage pea Banat's J. of Biotechn. IV(7), 74-79 (2013)

4. V. Vasileva, Aboveground to root biomass ratios in pea and vetch after treatment with organic fertilizer 
Global J. of Environmental Science and Management (GJESM) 1(2), 71-74 (2015)

5. V. Vasileva, Productivity of dry aboveground and root mass in mixtures J. of Mountain Agricult. on the Balkans 17, 956-969 (2014)

6. V.M. Kosolapov, I.A. Trofimov, Scientific support of Russian meadow farming Feed production 8, 4748 (2011)

7. D.V. Vinogradov, V.S. Konkina, Y.V. Kostin, M.M. Kruchkov, O.A. Zakharova, R.N. Ushakov, Developing the regional system of oil crops production management Res. J. of Pharmaceutical, Biological and Chemical Sci. (RJPBCS) 9(5), 12761284 (India, 2018)
8. I.S. Cohen, M.A. Ibarra, G.E. Arriaga, J.C. Paredes, M.A. Velasquez Valle, P.B. Hurtado, W.O. Bustamante, The impact of climatic patterns on runoff and irrigation water allocation in an arid watershed of northern Mexico Meteorol. Hydrol. Water Manage 6(2), 59-66 (2018)

9. J. Nyćkowiak, J. Leśny, J. Olejnik, L. Merbold, S. Niu, Regional carbon uptake of croplands in Poland between 1960 and 2009 Meteorol. Hydrol. Water Manage 6(1), 67-76 (2018)

10. L. Kuchar, A. Tiukało, Impact of environmental issues on research society and topic distribution in academic interest of Wroctaw Meteorol. Hydrol. Water Manage 6(2), 79-83 (2018) 